\title{
Editorials
}

\section{Improving the allograft valve: Does the immune response matter?}

\author{
Patrick G. Hogan, MBBS, PhD, FRACP, FRCPA
}

Mark F. O'Brien, MBBS, FRACS

See related article in 2003;126: 232-9.

From the Department of Clinical Immunology, Princess Alexandra Hospital, Woolloongabba, Brisbane, Australia.

Received for publication April 16, 2003; accepted for publication April 24, 2003.

Address for reprints: Patrick G. Hogan, $\mathrm{PhD}$, Director, Division of Immunology, Queensland Health Pathology Service, Princess Alexandra Hospital, Ipswich Rd, Woolloongabba QLD Australia 4102 (Email: Patrick_Hogan@health.qld.gov.au).

J Thorac Cardiovasc Surg 2003;126:1251-3

Copyright (C) 2003 by The American Association for Thoracic Surgery

$0022-5223 / 2003 \$ 30.00+0$

doi:10.1016/S0022-5223(03)01030-4

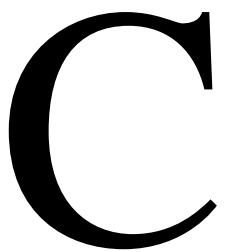

an an immunologic attack on cells expressing donor human leukocyte antigens (HLAs) contribute to human allograft valve (AV) deterioration? Not so, say the supporters of a mechanical mechanism of failure. ${ }^{1}$ They interpret anti-HLA antibodies in AV recipients $^{2-4}$ as irrelevant epiphenomena that result from mechanical failure liberating soluble HLA from the AV to stimulate the immune system. ${ }^{5}$ Unfortunately, this hypothesis is inconsistent with the appearance of anti-HLA antibodies within 30 days of implantation. ${ }^{3}$ Nevertheless, until recently, a pathogenic role for the immune response in $\mathrm{AV}$ degeneration was unproved because a link with functional outcomes was lacking.

The report by Baskett and colleagues ${ }^{6}$ in the July 2003 issue, together with similar conclusions from Dignan and associates, ${ }^{7}$ provides convincing evidence that a significant component of AV degeneration is immunologic. What is the mechanism linking AV deterioration and HLA mismatch between donor and recipient? The same relationship is shown in extensive multicenter studies of solid organ transplants between 0 to 6 antigen HLA mismatches and solid organ graft failure rates. ${ }^{8}$ The accepted underlying mechanism is an allogeneic T-cell response initiated by recognition of nonself HLA-DR on graft dendritic and endothelial cells, followed by an amplification phase against HLA-A and HLA-B molecules in addition to HLA-DR on most parenchymal cells. ${ }^{9}$ Such an immune response causing destruction of HLA-positive cells in the AV provides the most plausible explanation for the observation in the studies by Baskett and colleagues ${ }^{6}$ and Dignan and associates. ${ }^{7}$ Apart from antigen presentation, it is unlikely that the HLA system mediates any nonimmunologic function that could contribute to mechanical AV degeneration. Of interest is a tissue culture study reported by Hoekstra and coworkers ${ }^{10}$ predicting that mismatch between HLA-DR on human AV endothelial cells and lymphocytes would produce an allogeneic response potentially capable of damaging the AV.

An HLA mismatch effect is likely to be exaggerated by enhanced AV immunogenicity after shorter incubation times ${ }^{7}$ and in younger recipients who have heightened immune reactivity. ${ }^{7,11,12}$ Younger age is a very important determinant of decreased durability of the aortic AV used for aortic valve replacement. ${ }^{12}$ The 10 -year actuarial freedom from reoperation for structural degeneration in the 20 years and younger age group at implantation was $47 \%$ compared with $93 \%, 95 \%$, and $96 \%$ in those aged 21 to 40,41 to 60 , and more than 60 years, respectively. ${ }^{12}$

Looking for an HLA mismatch effect is inherently difficult because a paired donor and recipient will by chance have few of the 6 possible antigens in common. HLA-A and HLA-B are extremely polymorphic, and even the HLA-DR group consists of 16 discrete antigens. ${ }^{13}$ There have been 2 studies of similar design to that of Baskett and colleagues ${ }^{6}$ that fail to show a significant effect of HLA mismatch on 
AV longevity. ${ }^{14,15}$ Relatively short periods of observation, longer incubation times after harvest reducing AV immunogenicity, small numbers in one study, and older recipient cohorts are likely to have biased toward a negative result. More studies of similar design to that of Baskett and colleagues focusing on younger and larger recipient cohorts, fresher AVs, and longer mean periods of 5 to 10 years' surveillance are needed.

There is widespread interest in reducing the recipient's response to donor HLA in the hope that this will delay AV deterioration, particularly in young adults and children. There are no clinical data to suggest that immune suppression protects the AV from immunologic injury. Ideally, regimens such as low-dose cyclosporine ${ }^{16}$ given to protect the right-sided allograft after a Ross procedure should be subjected to trial. It is unlikely there exists enough enthusiasm for such trials in young cohorts because of the potential toxicities of the current antiproliferative, cytotoxic, and calcineurin-inhibiting agents. Animal studies are not promising, suggesting that the AV might be protected from immune destruction only for as long as combination immune suppression is continued (unpublished data). ${ }^{17}$

Could an immune response to the AV be minimized by using organ-sharing networks to direct HLA and ABOtyped AV in tissue banks to the best-matched recipient? Although this strategy is highly successful and economically sound for renal allografts, consideration of the size of the AV pool required, donor availability, standardization of $\mathrm{AV}$ preparation, and the costs of typing, harvesting, and transport would have to be balanced against the benefits of reduced reoperation rates in a younger population in which the AV is the preferred replacement.

Modification of the AV to reduce immunogenicity is an exciting and evolving area. The pivotal question underlying this endeavor is the nature of the AV cells that display HLA-DR so provocatively to the recipients' $T$ cells. Dendritic cells, also known as "professional" antigen-presenting cells are the most effective exponents of alloantigen presentation. ${ }^{18}$ Endothelial cells, also constitutively expressing HLA-DR, might carry out similar functions under the special conditions of cell culture or once exposed to inflammatory cytokines. ${ }^{10}$ Thus far, searches of the human aortic valve have found few dendritic cells, but the vascular subpopulation of dendritic cells might not express the expected surface antigens. ${ }^{19}$ Modifications of the AV designed to deplete antigen-presenting cells might also damage stromal cells and fibroblasts, with adverse effects on function.

Much research with some clinical application has been directed to tissue-engineered valves. In the hope of avoiding the immune response, decellularized AVs (both aortic and pulmonary) have been clinically implanted. Elkins and colleagues ${ }^{20}$ have reported 2 years' clinical experience with right-sided implants using AVs treated with the SynerGraft antigen reduction process (Cryolife Inc, Kennesaw, Ga) to encourage recellularization in vivo. An alternative direction used seeding of a decellularized pulmonary AV in vitro with autologous adult endothelial cells before implantation. ${ }^{21}$

Early promising results from these pioneering studies provide some hope that we might not have to resort to HLA matching or immune suppression. The immune system might not prove easy to bypass, however. The low incidence of anti-HLA antibodies reported by Elkins and associates ${ }^{22}$ in recipients of decellularized AVs is reassuring but nevertheless raises a note of caution because these antibodies might not be a sensitive marker for the alloreactive cells that are likely to be the actual agents of AV cell injury. ${ }^{3}$

\section{References}

1. Mitchell RN, Jonas RA, Schoen FJ. Pathology of explanted cryopreserved allograft heart valves: comparison with aortic valves from orthotopic heart transplants. J Thorac Cardiovasc Surg. 1998;115:11828.

2. Smith JD, Ogino H, Hunt D, Laylor RM, Rose ML, Yacoub MH. Humoral immune response to human aortic valve allografts. Ann Thorac Surg. 1995;60(suppl):S127-30.

3. Hogan P, Duplock L, Green M, Smith S, Gall K, Frazer I, et al. Human aortic valve allografts elicit a donor-specific immune response. J Thorac Cardiovasc Surg. 1996;112:1260-7.

4. Hawkins JA, Breinholt JP, Lambert LM, Fuller TC, Profaizer T, McGough EC, et al. Class I and class II anti-HLA antibodies after implantation of cryopreserved allograft material in pediatric patients. J Thorac Cardiovasc Surg. 2000;119:324-30.

5. Dignan R, O'Brien M, Hogan P, Thornton A, Fowler K, Byrne D, et al. Evidence for aortic valve allograft structural deterioration secondary to immune response. J Heart Valve Dis. In press.

6. Baskett RFJ, Nanton MA, Warren AE, Ross DB. Human leukocyte antigen-DR and ABO mismatch are associated with accelerated homograft valve failure in children: implications for therapeutic interventions. J Thorac Cardiovasc Surg. 2003;126:232-9.

7. Dignan R, O'Brien M, Hogan P, Passage J, Stephens F, Thornton A, et al. Influence of HLA matching and associated factors on aortic valve homograft function. J Heart Valve Dis. 2000;9:504-11.

8. Opelz G, Wujciak T, Dohler B, Scherer S, Mytelineos J. HLA compatibility and organ transplant survival collaborative transplant study. Rev Immunogenet. 1999;1:334-42.

9. McCluskey J, Peh CA. The human leukocyte antigens and clinical medicine: an overview. Rev Immunogenet. 1999;1:3-20.

10. Hoekstra F, Knoop C, Zohara A, Jutte N, Mochtar B, Bos E, et al. Stimulation of immune-competent cells in vitro by human cardiac valve-derived endothelial cells. Ann Thorac Surg. 1995;60(suppl): S131-4.

11. Clarke DR, Campbell DN, Hayward AR, Bishop DA. Degeneration of aortic valve allografts in young recipients. J Thorac Cardiovasc Surg. 1993;105:934-42.

12. O'Brien MF, Harrocks S, Stafford EG, Gardner MAH, Pohlner PG, Tesar PJ, et al. The homograft aortic valve: a 29year, $99.3 \%$ follow up of 1022 valve replacements. J Heart Valve Dis. 2001;10:334-45.

13. Schreuder GMTh. HLA typing by alloantibodies and monoclonal antibodies. In: Bidwell JL, Navarrete C, editors. Histocompatibility testing. London: Imperial College Press; 2001. p. 49-63.

14. Smith JD, Hornich PI, Rasmi N, Rose M, Yacoub MH. Effect of HLA mismatching and antibody status on "homovital" aortic valve homograft performance. Ann Thorac Surg. 1998;66(suppl):S212-5.

15. Bechtel MJF, Bartels C, Schmidtke C, Skibba W, Muller-Steinhardt $\mathrm{M}$, Kluter $\mathrm{H}$, et al. Does histocompatibility affect homograft valve function after the Ross procedure? Circulation. 2001;104(suppl I): $25-8$. 
16. Al-Halees Z, Pieters F, Qadoura F, Shahid M, Al-Amri M, Al-Fadley F. The Ross procedure is the procedure of choice for congenital aortic valve disease. $J$ Thorac Cardiovasc Surg. 2002;123:437-42.

17. Legare JF, Ross DB, Issekutz TB, Ruigrok W, Creaser K, Hirsch GM, et al. Prevention of allograft heart failure in a rat model. $J$ Thorac Cardiovasc Surg. 2001;122:310-7.

18. Hart DNJ. Dendritic cells: unique leukocyte populations which control the primary immune response. Blood. 1997;90:3245-87.

19. Oei FB, Stegmann AP, van der Ham F, Zondervan PE, Vaessen LM, Baan CC, et al. The presence of immune stimulatory cells in fresh and cryopreserved donor aortic and pulmonary valve allografts. J Heart Valve Dis. 2002;11:315-24.

20. Elkins RC, Goldstein S, Hewitt CW, Walsh SP, Dawson PE, Ollerenshaw JD, et al. Recellularization of heart valve grafts by a process of adaptive remodelling. Semin Thorac Cardiovasc Surg. 2001;13(suppl I):87-92.

21. Elkins RC. Tissue-engineered valves [editorial]. Ann Thorac Surg. 2002;74:1434.

22. Elkins RC, Lane MM, Capps SB, McCue C, Dawson PE. Humoral immune response to allograft valve tissue pretreated with an antigen reduction process. Semin Thorac Cardiovasc Surg. 2001;13(suppl I):82-6.

\section{JTCVS On-Line Manuscript Submission and Review}

\section{Please visit http://www.editorialmanager.com/jtcvs/}

Effective September 15, 2001, authors and reviewers may submit manuscripts and reviews electronically via Editorial Manager, our new Web-based system with full electronic submission, review, and status update capabilities.

As we move from paper to electronic submissions, the Editorial Office will make proxy submissions of all manuscripts accompanied by a diskette containing the electronic files of the text, tables, and figures. Editors, authors, and reviewers will receive automatic e-mails when significant events occur.

We strongly encourage all authors and reviewers to use Editorial Manager. Although we will continue to accommodate the submission of paper manuscripts for some months, our goal is to be completely electronic within 9 to 12 months.

All individuals currently in our database for whom we have e-mail addresses will receive via e-mail a system-assigned username and password that can be used to log in to the system without prior registration. All those not receiving the e-mail must register the first time they use the system.

As with any broad systemic change, the conversion to the new system will take some time to complete. We ask your patience as we replace our in-office database with the new system. We also encourage you to take advantage of the speed and efficiency that the new system will provide for us all: editor, author, reviewer, and publisher. 